\title{
Seasonal modulation of the Asian summer monsoon between the Medieval Warm Period and Little Ice Age: a multi model study
}

\author{
Youichi Kamae $e^{1,2^{*}}$ (D) Toshi Kawana ${ }^{3}$, Megumi Oshiro ${ }^{4}$ and Hiroaki Ueda ${ }^{1}$
}

\begin{abstract}
Instrumental and proxy records indicate remarkable global climate variability over the last millennium, influenced by solar irradiance, Earth's orbital parameters, volcanic eruptions and human activities. Numerical model simulations and proxy data suggest an enhanced Asian summer monsoon during the Medieval Warm Period (MWP) compared to the Little Ice Age (LIA). Using multiple climate model simulations, we show that anomalous seasonal insolation over the Northern Hemisphere due to a long cycle of orbital parameters results in a modulation of the Asian summer monsoon transition between the MWP and LIA. Ten climate model simulations prescribing historical radiative forcing that includes orbital parameters consistently reproduce an enhanced MWP Asian monsoon in late summer and a weakened monsoon in early summer. Weakened, then enhanced Northern Hemisphere insolation before and after June leads to a seasonally asymmetric temperature response over the Eurasian continent, resulting in a seasonal reversal of the signs of MWP-LIA anomalies in land-sea thermal contrast, atmospheric circulation, and rainfall from early to late summer. This seasonal asymmetry in monsoon response is consistently found among the different climate models and is reproduced by an idealized model simulation forced solely by orbital parameters. The results of this study indicate that slow variation in the Earth's orbital parameters contributes to centennial variability in the Asian monsoon transition.
\end{abstract}

Keywords: Asian monsoon, Medieval Warm Period, Little Ice Age, Meridional thermal gradient, Orbital forcing

\section{Introduction}

The last millennium, from 850 A.D. to the present, is a key period in understanding Earth's climate response to external forcing and its internal variability on decadal-to-centennial timescales (e.g., Crowley 2000; Jones et al. 2009; PAGES 2k Consortium 2013; Smerdon and Pollack 2016). A variety of instrumental and proxy records indicate that the global climate has experienced remarkable fluctuations during this period due to large volcanic eruptions (e.g., Miller et al. 2012; Schurer et al. 2014; Yang and Jiang 2015; Liu et al.

\footnotetext{
* Correspondence: kamae.yoichi.fw@u.tsukuba.ac.jp

${ }^{1}$ Faculty of Life and Environmental Sciences, University of Tsukuba, 1-1-1 Tennoudai, Tsukuba, Ibaraki 305-8506, Japan

${ }^{2}$ Scripps Institution of Oceanography, University of California San Diego, 9500 Gilman Drive, MC 206, La Jolla, CA 92093-0206, USA

Full list of author information is available at the end of the article
}

2016), variations in total solar irradiance (TSI) (Gray et al. 2010; Lean 2010), Earth's orbital parameters (Berger and Loutre 1991; Kaufman et al. 2009), greenhouse gases (GHGs) (e.g., Schmidt et al. 2011), and internal climate variability. On a centennial timescale, anthropogenic global warming accompanying rapid GHG increases since the 19th century is the most remarkable climate fluctuation (e.g., Bradley et al. 2003; Jones and Mann 2004; Ammann et al. 2007; Phipps et al. 2013; Masson-Delmotte et al. 2014). In addition, predominant global climate perturbation from the Medieval Warm Period (MWP) of 950-1250 A.D. to the Little Ice Age (LIA) of 1400-1700 A.D. (e.g., Mann et al. 2009) has also attracted much attention because it is the most recent example of long-term, naturallygenerated global climate variability (e.g., Liu et al. 2011; Man et al. 2012; Otto-Bliesner et al. 2016; Shi et al., 2016a, b). 
Historical variations in the Asian monsoon have important links to environmental changes and the cultural development of human societies over South and East Asia (Clift and Plumb 2008; Fu et al. 2008). Past monsoon variability has been addressed both from paleoenvironmental reconstructions based on proxy records and from numerical climate simulations (e.g., Kutzbach et al. 2008; Zhang et al. 2008; Battisti et al. 2014; Masson-Delmotte et al. 2014; Fallah and Cubasch 2015; Yan et al. 2015). Variations in summertime temperature over the continents in the Northern Hemisphere $(\mathrm{NH})$ in response to seasonal insolation anomalies brought on by changes in orbital parameters (including the longitude of perihelion precession) are an essential factor in past monsoon variability (e.g., COHMAP members 1988; Mohtadi et al. 2016). The land-sea contrast in tropospheric temperature favored by summertime insolation is further amplified by latent heating of the monsoon rainfall that establishes deep-tropospheric monsoon circulation (e.g., Li and Yanai 1996; Webster et al. 1998; Dai et al. 2013; Wu et al. 2015; Zhang et al. 2016). On a millennial timescale, past monsoon variability has largely been controlled by precession variability (e.g., Kutzbach et al. 2008; Merlis et al. 2013; Mohtadi et al. 2016) and amplified by obliquity variability (Bosmans et al. 2015; Wu et al. 2016) as it changed the large-scale thermal contrast between land and sea. Oxygen isotope-based reconstructions of Indian and East Asian monsoon intensity show coherent variability on a millennial timescale (e.g., Battisti et al. 2014; Kathayat et al. 2016; Mohtadi et al. 2016), suggesting that orbital forcing has a strong effect on continental-scale monsoon variability.

On a centennial timescale, orbital forcing also played an important role in long-term differences of the intertropical convergence zone and associated monsoon activity between the MWP and LIA (e.g., Sachs et al. 2009; Oppo et al. 2009; Schneider et al. 2014; Yan et al. 2015). Major characteristics of the monsoon during these two periods have been reconstructed by proxy records that are broadly available across Asia, especially in China (e.g., Chen et al. 2015). Historical documents and speleothem records suggest that precipitation over northern China associated with the East Asian summer monsoon increased significantly during the MWP and decreased during the LIA (Ren and Zhang 1996; Wang et al. 2001; Qian et al. 2003; Tan 2007). Oxygen isotope data retrieved from Indian stalagmite records also suggest an enhanced Indian summer monsoon during the MWP (Sinha et al. 2011, 2015; Berkelhammer et al. 2014). The coherent enhancement of the East Asian and Indian summer monsoon during the MWP, as compared to the LIA suggests that orbitally forced summertime insolation variability is also a key factor for centennial-scale monsoon variability during the last millennium.

Monsoon variability over the last millennium has also been addressed by numerical simulations based on single (Fan et al., 2009b; Liu et al. 2009, 2011; Man et al. 2012; Polanski et al. 2014) or multiple climate models (Fallah and Cubasch 2015; Rojas et al. 2016; Shi et al., 2016a, b; Yang and Jiang 2017) estimated as part of the Paleoclimate Modeling Intercomparison Project Phase 3 (PMIP3) (Otto-Bliesner et al. 2009). The climate models reproduced, in large part, the enhanced Asian summer monsoon and increased precipitation over northern China $\left(35^{\circ} \mathrm{N}-42^{\circ} \mathrm{N}, 100^{\circ} \mathrm{E}-120^{\circ} \mathrm{E}\right)$ during the MWP (e.g., Man et al. 2012; Shi et al., 2016b), consistent with the proxy evidence. The enhanced Asian summer monsoon during the MWP, as compared to the LIA, is associated with larger land-sea temperature contrasts (e.g., Man et al. 2012; Shi et al., 2016a, b) induced by strong summertime insolation (Fig. 1; detailed in the Methods section). These large-scale features of the Asian summer monsoon during the MWP are consistent among multiple climate model simulations (Shi et al., 2016a) with nonnegligible inter-model spread in regional rainfall patterns (Shi et al., 2016b).

In addition to seasonal-mean features, seasonal transitions (changes in onset and withdrawal timing) are also important aspects of paleo-monsoon variability (e.g.,

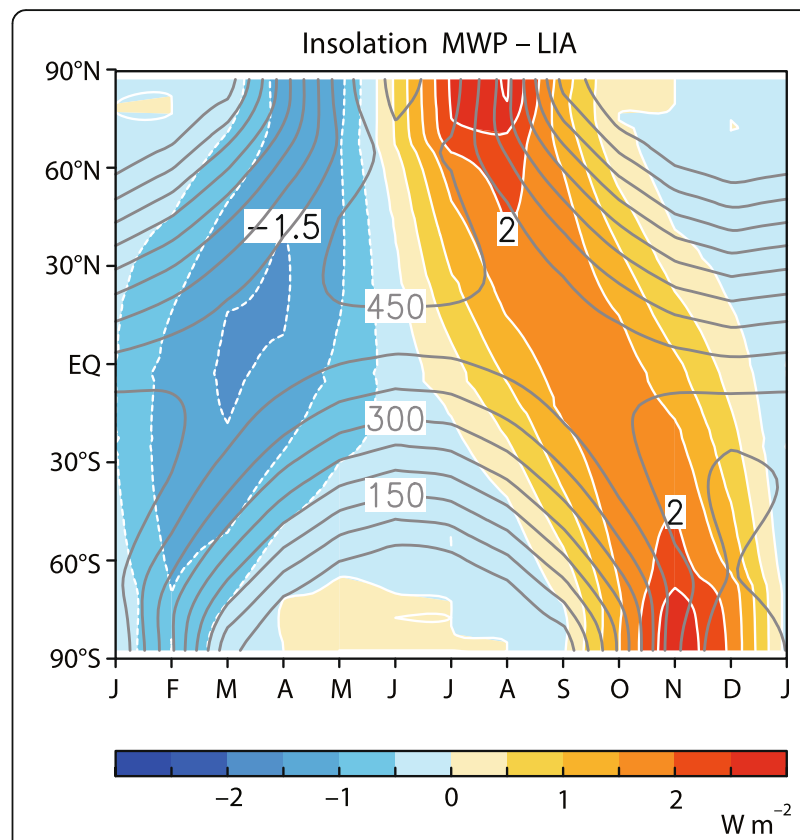

Fig. 1 Seasonal variation of insolation $\left(\mathrm{W} \mathrm{m}^{-2}\right)$ at the top of the atmosphere averaged over 10 PMIP3 models. Shading represents the anomaly between the MWP (950-1250 A.D.) and LIA (1400-1800 A.D.; hereafter $\mathrm{ML}$ anomaly). Contours represent climatology in the LIA 
Ueda et al. 2011; Shi 2016; Kong et al. 2017). The peak $\mathrm{NH}$ insolation anomaly due to the Earth's orbit variability is not necessarily concurrent with the summer solstice. As for the difference between the MWP and LIA, time-varying precession (detailed in the Methods section) leads to a positive $\mathrm{NH}$ insolation anomaly with its peak in August to September as shown in Fig. 1 (Kaufman et al. 2009). In contrast, a negative insolation anomaly is found in May to June, around the timing of the monsoon onset, implying a seasonally asymmetric response of the Asian summer monsoon to orbital forcing (e.g., Shi 2016; Kong et al. 2017) during the last millennium.

This study reveals that the slow variation in orbital parameters from the MWP to the LIA results in an inverse response of the Asian monsoon between early and late summer, as shown by simulations of the last millennium using multiple climate models and sensitivity experiments by an atmosphere-ocean coupled general circulation model (AOGCM). The results indicate that centennial Asian monsoon variability shown in previous works is not seasonally uniform, but rather characterized by changes in the seasonal transition of the monsoon between the MWP and LIA, which is suggestive for past, present and future climate variability.

\section{Methods/Experimental}

\section{PMIP3 multiple model ensemble}

We analyzed climate simulations of the last millennium (850-1850 A.D.) of 10 AOGCMs (hereafter denoted as past1000) from PMIP3 (Otto-Bliesner et al. 2009) and the Coupled Model Intercomparison Project phase 5 (CMIP5) (Taylor et al. 2012). Table 1 summarizes the models used in this study. Although simulation outputs from 11 models are available from the CMIP5 Earth

Table 1 List of PMIP3 models used in this study. The TSI and volcanic columns indicate forcing data sets prescribed in the models. V11: Vieira et al. (2011), S09: Steinhilber et al. (2009), C00: Crowley (2000), JM04: Jones and Mann (2004), DB09: Delaygue and Bard (2009), G08: Gao et al. (2008), C08: Crowley et al. (2008)

\begin{tabular}{llll}
\hline Model & Atmospheric resolution & TSI & Volcanic \\
\hline BCC-CSM1-1 & $2.813^{\circ} \times 2.791^{\circ}, \mathrm{L} 26$ & $\mathrm{~V} 11$ & $\mathrm{G} 08$ \\
CCSM4 & $1.25^{\circ} \times 0.942^{\circ}, \mathrm{L} 26$ & $\mathrm{~V} 11$ & $\mathrm{G} 08$ \\
CSIRO-Mk3L-1-2 & $5.625^{\circ} \times 3.186^{\circ}, \mathrm{L} 18$ & $\mathrm{~S} 09$ & $\mathrm{C} 98$ \\
FGOALS-gl & $5.0^{\circ} \times 4.103^{\circ}$ & $\mathrm{C} 00, \mathrm{JM} 04$ & $\mathrm{C} 00, \mathrm{JM} 04$ \\
FGOALS-S2 & $2.813^{\circ} \times 2.791^{\circ}, \mathrm{L} 26$ & $\mathrm{~V} 11$ & $\mathrm{G} 08$ \\
GISS-E2-R & $2.5^{\circ} \times 2.0^{\circ}, \mathrm{L} 40$ & $\mathrm{~V} 11$ & $\mathrm{G} 08$ \\
HadCM3 & $3.75^{\circ} \times 2.5^{\circ}, \mathrm{L} 19$ & $\mathrm{~S} 09$ & $\mathrm{C} 98$ \\
IPSL-CM5A-LR & $3.75^{\circ} \times 1.875^{\circ}, \mathrm{L} 39$ & $\mathrm{~V} 11$ & $\mathrm{G} 08$ \\
MPI-ESM-P & $1.875^{\circ} \times 1.865^{\circ}, \mathrm{L} 47$ & $\mathrm{~V} 11$ & $\mathrm{C} 1$ \\
MRI-CGCM3 & $1.125^{\circ} \times 1.125^{\circ}, \mathrm{L} 48$ & $\mathrm{DB} 09$ & $\mathrm{G} 08$ \\
\hline
\end{tabular}

System Grid Federation data server as of 01 February 2017, we excluded output from the MIROC-ESM due to climate drift in its simulation (Sueyoshi et al. 2013).

External forcing factors for the past1000 runs include time-varying TSI, volcanic eruptions, GHGs, land use, and orbital parameters. Details of the experimental setup are found in Schmidt et al. (2011, 2012). Note that the models employed different TSI and volcanic forcing data as listed in Table 1 (see Schmidt et al. 2011, 2012 for details). This difference contributes partly to inter-model spread among simulation outputs. Varying land uses over time such as gradually increasing cropland and pasture area (Schmidt et al. 2012) prescribed in these simulations can affect regional climate variability, including surface temperature and monsoon systems (Takata et al. 2009; He et al. 2014). Historical GHG concentrations $\left(\mathrm{CO}_{2}, \mathrm{CH}_{4}\right.$ and $\left.\mathrm{N}_{2} \mathrm{O}\right)$ are derived from ice cores in Antarctica (Schmidt et al. 2011). Orbital parameters that vary over time, including eccentricity, obliquity and precession result in low-frequency variability in the seasonal-latitudinal distribution of insolation as shown in Fig. 1 (Kaufman et al. 2009; Schmidt et al. 2011). Table 2 summarizes the orbital parameters averaged during the MWP and LIA. The negative early summer insolation anomaly in the $\mathrm{NH}$ during the MWP relative to the LIA is largely due to a shift of the perihelion (Schmidt et al. 2011). In this study, we compare long-term mean climates of the MWP and LIA. Note that we determined the MWP climatology in FGOALS-gl by averaging the period from 1000 to 1250 A.D. because only outputs after 1000 A.D. are provided by this model.

Figure 1 shows the 10-model mean insolation anomaly (MWP minus LIA; hereafter ML) at the top of the atmosphere. The seasonal $\mathrm{NH}$ insolation anomaly due to orbital forcing, especially precession, is remarkable $\left(-1.5-3 \mathrm{~W} \mathrm{~m}^{-2}\right)$ despite its slow variation on a centennial timescale (e.g., the difference in perihelion is $7.28^{\circ}$; Table 2). A large positive anomaly in August and September $\left(1.5-2.5 \mathrm{~W} \mathrm{~m}^{-2}\right)$, in contrast to a small anomaly in June (Fig. 1), enhances the land-sea thermal gradient and the Asian summer monsoon (Man et al. 2012). In contrast, a broad negative insolation anomaly is found in the $\mathrm{NH}$ in the winter-to-spring period (peaking at $-1.5--0.5 \mathrm{~W} \mathrm{~m}^{-2}$ in March to April), resulting in the strong seasonal reversal of the $\mathrm{NH}$ insolation anomaly. This seasonally asymmetric forcing potentially

Table 2 Orbital parameters for MRI-CGCM2.3 orbital forcing runs

\begin{tabular}{llll}
\hline & Eccentricity & Obliquity & Precession \\
\hline Medieval Warm Period & 0.017059 & $23.556^{\circ}$ & $87.52^{\circ}$ \\
Little Ice Age & 0.016884 & $23.498^{\circ}$ & $95.20^{\circ}$ \\
\hline
\end{tabular}


affects the seasonal transition of the Asian summer monsoon (e.g., Kong et al. 2017).

\section{Idealized orbital forcing experiments in an AOGCM}

The Asian monsoon simulated in the past 1000 runs is influenced by the time-varying external forcing listed above. The seasonally asymmetric orbital forcing (Fig. 1) may have an especially strong effect on the Asian monsoon (Ueda et al. 2011; Man et al. 2012; Kong et al. 2017). To evaluate the contribution of the orbital forcing to the ML anomaly in the Asian monsoon, we conducted idealized simulations using an AOGCM, the Meteorological Research Institute (MRI) Coupled General Circulation Model version 2.3 (MRI-CGCM2.3) (Yukimoto et al. 2006a).

MRI-CGCM2.3 has widely been used for future climate projections (Yukimoto et al. 2006b) and for paleoclimate simulations including the mid-Holocene, 6 ka (Kitoh et al. 2007; Braconnot et al. 2007), Last Glacial Maximum (LGM), 21 ka (Ueda et al. 2011), and Pliocene, 3.3-3.0 Ma (Kamae and Ueda 2012; Kamae et al. 2016). Ueda et al. (2011) used this model to examine the seasonal transition of the Asian monsoon during the LGM. This model is capable of reproducing general features of the Asian summer monsoon including its seasonal transition (Inoue and Ueda 2009). Its atmospheric model is a spectral model with T42 spatial resolution (approximately $2.8^{\circ}$ ) that uses 30 vertical layers. The ocean component is a Bryan-Cox-type global ocean model with a horizontal resolution of $2.5^{\circ}$ longitude and $2.0^{\circ}-0.5^{\circ}$ latitude and 23 layers. We integrated the model without any flux adjustments. The $\mathrm{CO}_{2}$ concentration and solar constant were set to $280 \mathrm{ppmv}$ and $1365 \mathrm{~W} \mathrm{~m}^{-2}$, respectively. We set the other boundary conditions as presented in Table 1 of Kamae et al.
(2016) for their pre-industrial control simulations, and integrated the model for 500 years to spin up the model in the same way as Kamae et al. (2016) had done for their pre-industrial control run. Next, we changed the orbital parameters as shown in Table 2 and integrated the model for another 55 years for the MWP and LIA cases. In this paper, we call these two simulations "orbital forcing runs." We performed an ensemble of five member simulations for each with slightly different initial conditions derived from the pre-industrial run with 5 -year intervals. We determined the climatology as an average over the last 50 years for the individual runs (250 years in total). Note that this study only addresses the transient response of the Asian monsoon to radiative forcing on a multi-decade timescale. Effects of long-term deep-ocean temperature variations and overturning circulations on the Asian monsoon during the MWP and LIA are not examined in this study.

\section{Results and Discussion}

Seasonally asymmetric response in PMIP3 model simulations In this section, we compare the seasonal evolutions of the Asian monsoons during the MWP and LIA simulated in multiple PMIP3 models. Figures 2 and 3 show the ML rainfall and atmospheric circulation anomalies over the Asian monsoon region averaged for April-May-June (AMJ) and August-SeptemberOctober (ASO). For spatial patterns, we chose these months to compare general features of late spring to early summer (around the monsoon onset) period, with its negative insolation anomaly (Fig. 1) and late summer to early fall (around monsoon withdrawal), with its positive insolation anomaly, and to emphasize the seasonal asymmetry in the atmospheric circulation and rainfall responses. Note that the timing of seasonal monsoon transitions varies by region (e.g., onset

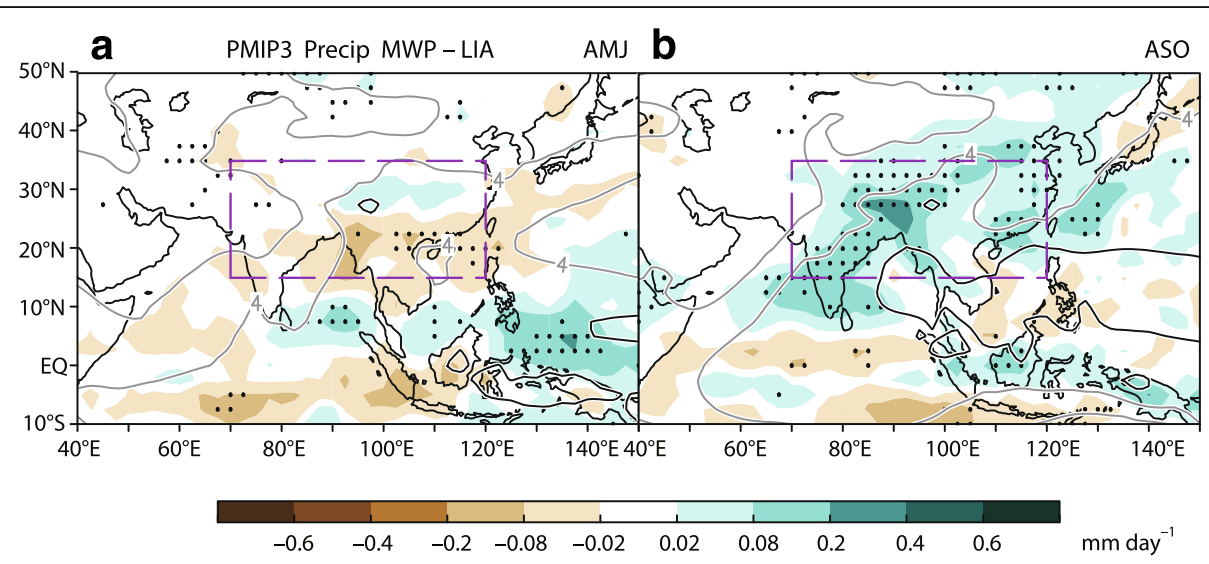

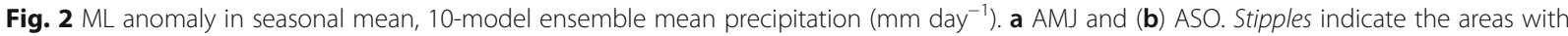
95\% statistical confidence. Gray (1 and $4 \mathrm{~mm} \mathrm{may}^{-1}$ ) and black ( $8 \mathrm{~mm}$ day ${ }^{-1}$ ) contours represent the climatology of precipitation during the LIA. The dashed purple rectangle indicates the area examined in Table 3 


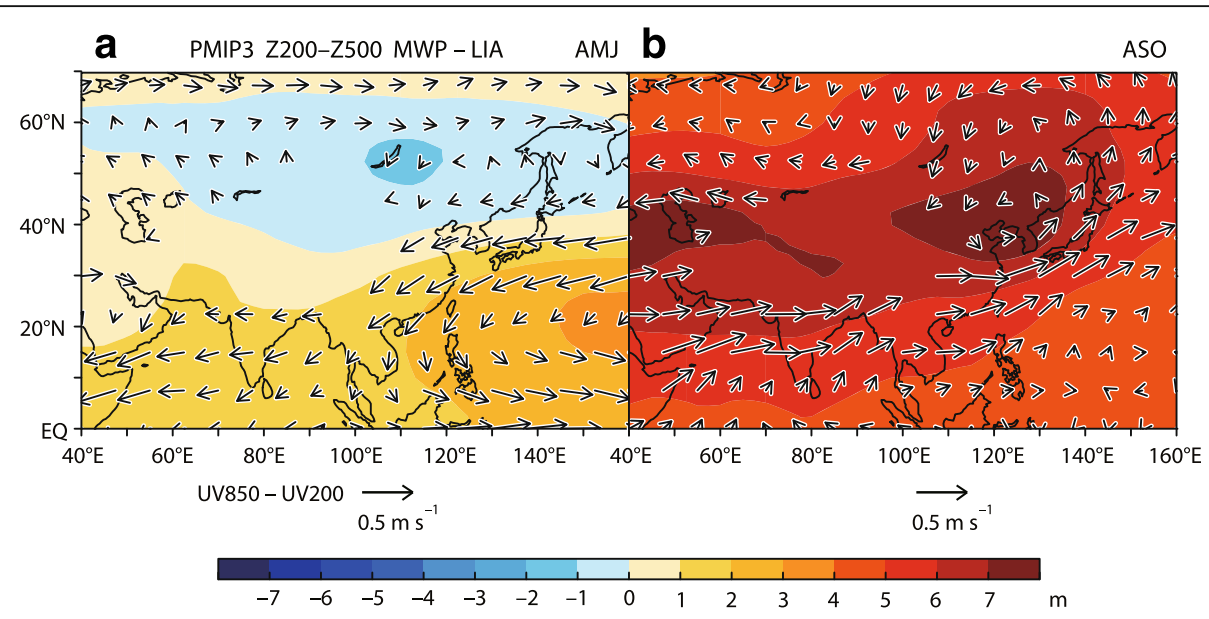

Fig. 3 Similar to a Fig. 2a and b Fig. 2b, but for tropospheric thickness (m) between the 200 and $500 \mathrm{hPa}$ levels. Vectors indicate vertical wind shear $\left(\mathrm{m} \mathrm{s}^{-1}\right)$ between 850 and $200 \mathrm{hPa}$ levels

over the South China Sea in mid-May is 1 month earlier than that over Korea and Japan in early to mid-June; e.g., Tao and Chen 1987; Wang and Lin, 2002; Ueda et al. 2009). In this study, our main focus is continental-scale Asian monsoon variability including the South and East Asian monsoons. We also show seasonal evolution of the ML anomalies in individual months (detailed below).

In the 10-model ensemble mean, ASO rainfall is more active over Asia during the MWP than during the LIA (Fig. 2b), similar to June-July-August (JJA) mean anomalies shown in previous studies (Man et al. 2012; Shi et al., 2016a). The positive ML anomaly, which has high inter-model correspondence, can be found broadly over the Indian subcontinent, northeastern India, Southwest China and Eastern China. The mid-to-upper tropospheric thickness (200-500 hPa; Fig. 3b), an index for mid-to-upper tropospheric temperature (e.g., Dai et al. 2013; Kamae et al. 2017; see the Introduction section), shows general warming over the Eurasian continent, especially over the middle latitudes. In the PMIP3 multimodel mean, the summertime climatological position of the upper-tropospheric South Asian High (Shi et al,, 2016a) and its seasonal evolution (intensification and northward shift from spring to summer, followed by zonal expansion in summer; e.g., Yanai and Wu 2006) are well reproduced (figure not shown). The spatial pattern of vertical wind shear $(850-200 \mathrm{hPa})$ indicates enhanced low-level (upper-level) monsoon westerly (easterly) over the Arabian Sea, Indian subcontinent, Bay of Bengal, Southeast Asia, South China Sea, and Eastern China (Fig. 3b). Tropospheric temperature and associated vertical wind shear are widely used as indices for Asian monsoon intensity (Webster and Yang 1992; Li and Yanai 1996; Kawamura 1998; Kamae et al. 2014).
These anomalies correspond well with the climatological structure of the Asian monsoon (Fig. 6a in Kamae et al. 2017), indicating a general enhancement of the Asian summer monsoon. The spatial patterns of tropospheric warming and associated anomalous atmospheric circulation and rainfall are partly dependent on which model is used (Shi et al., 2016a, b) especially over the western North Pacific (detailed below), but mid-latitude Eurasian continental warming and the enhanced monsoon are consistent among the different climate model simulations as shown in Figs. 2b and 3b (Man et al. 2012; Shi et al., 2016a, b).

In contrast to the enhanced late summer monsoon, AMJ-mean precipitation (Fig. 2a) shows a negative anomaly over Southeast Asia and Southern China and a positive anomaly over the western tropical Pacific. Figure 4a shows the climatological seasonal variation of rainfall averaged over $15^{\circ} \mathrm{N}-35^{\circ} \mathrm{N}$ and its $\mathrm{ML}$ anomaly. The model captures an earlier climatological monsoon onset over Southeast Asia $\left(90^{\circ} \mathrm{E}-120^{\circ} \mathrm{E}\right.$ in May; Tao and Chen 1987; Wang and Lin, 2002) than over the Arabian Sea $\left(60^{\circ} \mathrm{E}-80^{\circ} \mathrm{E}\right.$ in June to July). The negative AMJ rainfall anomaly over Southeast Asia is distinct from the positive ASO anomaly $\left(70^{\circ} \mathrm{E}-120^{\circ} \mathrm{E}\right.$; Figs. $\left.2 \mathrm{~b}, 4 \mathrm{a}\right)$. Table 3 summarizes $M L$ anomalies in seasonal rainfall increment (ASO minus AMJ) averaged over the Asian region shown by the rectangles in Figs. 2 and $4 \mathrm{a}\left(15^{\circ} \mathrm{N}-35^{\circ} \mathrm{N}\right.$, $70^{\circ} \mathrm{E}-120^{\circ} \mathrm{E}$ ). Although inter-model spread of the JJAmean ML anomaly in the Asian monsoon rainfall is remarkable (Shi et al., 2016b), the seasonal asymmetry in the ML rainfall anomaly is robust among the PMIP3 models $\left(0.09 \pm 0.03 \mathrm{~mm} \mathrm{day}{ }^{-1}\right)$. Note that an East Asian-Western North Pacific monsoon index, determined by a meridional gradient of low-level zonal wind $\left(20^{\circ} \mathrm{N}-30^{\circ} \mathrm{N}, 110^{\circ} \mathrm{E}-140^{\circ} \mathrm{E}\right.$ minus $\left.5^{\circ} \mathrm{N}-15^{\circ} \mathrm{N}, 90^{\circ} \mathrm{E}-130^{\circ} \mathrm{E}\right)$ 

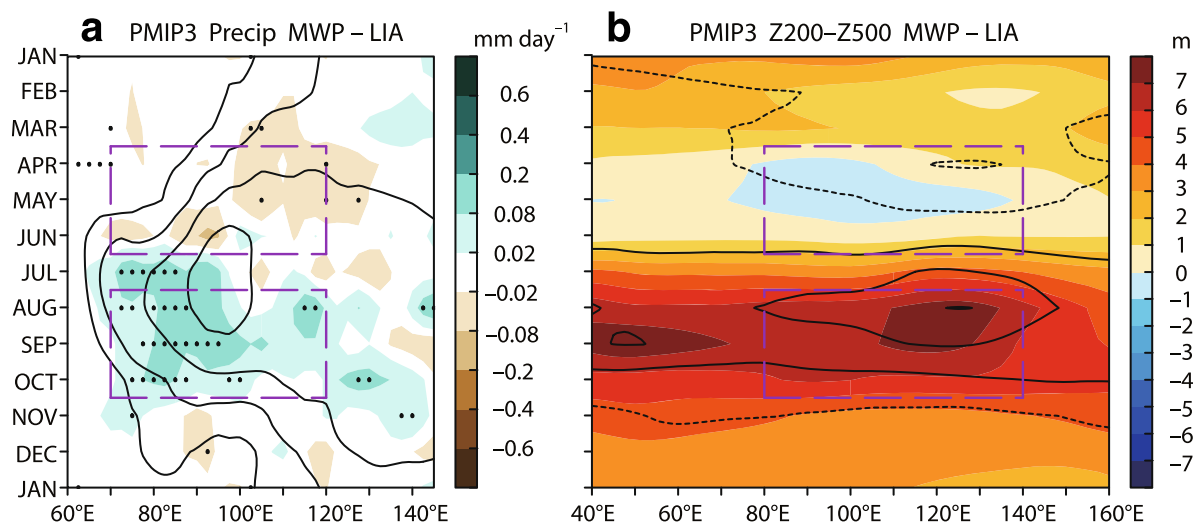

Fig. 4 Seasonal evolutions of $\mathrm{ML}$ anomalies in precipitation and tropospheric thickness. a Precipitation $\left(\mathrm{mm}^{-1}\right.$ day $\left.^{-1}\right)$ averaged over $15^{\circ} \mathrm{N}-35^{\circ} \mathrm{N}$. Contours represent climatology $\left(1,2,4,8 \mathrm{~mm}\right.$ day $\left.^{-1}\right)$ during the LIA. Stipples indicate the areas with $95 \%$ statistical confidence. Dashed purple rectangles indicate the months and area examined in Table 3. b Thickness $(\mathrm{m})$ between 200 and $500 \mathrm{hPa}$ levels averaged over $25^{\circ} \mathrm{N}-60^{\circ} \mathrm{N}$. Contours represent the difference between $25^{\circ} \mathrm{N}-60^{\circ} \mathrm{N}$ and $\mathrm{EQ}-25^{\circ} \mathrm{N}(-6,-4,-2,0,2,4,6 \mathrm{~m})$

(Wang et al. 2008), shows a large intermodel spread (0.05 $\pm 0.28 \mathrm{~m} \mathrm{~s}^{-1}$ ). The rainfall anomaly over East Asia is also highly dependent on which model is assumed (Shi et al., 2016b). The model diversity may be related to a large intermodel spread in the ML anomaly in the Pacific Ocean (Shi et al., 2016b). The possible importance of the Pacific Ocean to the East Asian monsoon anomaly is addressed in the Discussion section.

Seasonally asymmetric responses can also be found in monsoon circulation and continental-scale temperature patterns. Figure 3a shows AMJ-mean tropospheric thickness and vertical wind shear. In contrast to ASO (Fig. 3b), a negative anomaly with its peak at $50^{\circ} \mathrm{N}$ is broadly found over the Eurasian continent. An anomalous meridional temperature gradient associated with this cooling results in a low-level easterly wind anomaly over East and South Asia $\left(5^{\circ} \mathrm{N}-45^{\circ} \mathrm{N}\right)$. This easterly wind anomaly is indicative of a delay in the seasonal migration of the Asian summer monsoon (reversal of wind direction). Figure $4 \mathrm{~b}$ shows the meridional tropospheric temperature gradient $\left(25^{\circ} \mathrm{N}-60^{\circ} \mathrm{N}\right.$ minus EQ $\left.-15^{\circ} \mathrm{N}\right)$ over Asia. Except for the AMJ period, the $\mathrm{NH}$ mid-latitude tropospheric temperature is higher during the MWP than during the LIA. Figure $5 \mathrm{a}$ shows the simulated annual-mean ML anomaly in sea surface temperature (SST). In the PMIP3 ensemble mean, the surface and troposphere over the $\mathrm{NH}$ middle latitudes are generally warmer during the MWP than in the LIA in response to external forcing including GHGs and orbital forcing (Schmidt et al. 2011, 2012). Despite the generally warmer conditions, a widespread cool anomaly is found in the AMJ period (Figs. 3a, 4b), consistent with the anomalies in circulation and precipitation over Asia having opposite signs to those during ASO (Figs. 2, 3, 4). This continentalscale structure of the tropospheric temperature anomaly is a robust feature among the PMIP3 models (Table 3). Note that the East Asian-Western North Pacific monsoon index (Wang et al. 2008) is largely consistent with the South Asian monsoon (stronger monsoons in ASO than in AMJ) but shows a large inter-model spread (Table 3). More details on the inter-model divergence are presented in the Discussion section.

\section{Effects of orbital forcing}

In the previous section, we showed that there is consistent seasonal reversal of sign in ML anomalies in precipitation, atmospheric circulation, and continental-scale tropospheric temperature among the PMIP3 models.

Table 3 Seasonal differences (ASO minus AMJ) and 95\% confidence intervals for precipitation (mm day ${ }^{-1}$ ), tropospheric thickness (between 200 and 500 hPa levels; m) over Asia, and an East Asian-Western North Pacific monsoon index, the meridional gradient of zonal wind at the $850 \mathrm{hPa}$ level (Wang et al. 2008) during the MWP relative to the LIA. PMIP3 (orbital forcing run) row represents a 10-model ensemble mean (5-member ensemble mean for the MRI-CGCM2.3 orbital forcing run)

\begin{tabular}{lll}
\hline & PMIP3 & Orbital forcing run \\
\hline Precip $\left(\mathrm{mm}\right.$ day $\left.{ }^{-1}\right) 15^{\circ} \mathrm{N}-35^{\circ} \mathrm{N}, 70^{\circ} \mathrm{E}-120^{\circ} \mathrm{E}$ & $0.09 \pm 0.03$ & $0.06 \pm 0.04$ \\
$Z 200-Z 500(\mathrm{~m}) 25^{\circ} \mathrm{N}-60^{\circ} \mathrm{N}, 80^{\circ} \mathrm{E}-140^{\circ} \mathrm{E}$ & $6.39 \pm 1.82$ & $6.52 \pm 1.60$ \\
$Z 200-Z 500(\mathrm{~m}) \mathrm{EQ}-25^{\circ} \mathrm{N}, 80^{\circ} \mathrm{E}-140^{\circ} \mathrm{E}$ & $3.18 \pm 1.02$ & $3.81 \pm 1.66$ \\
$Z 200-Z 500(\mathrm{~m}) 25^{\circ} \mathrm{N}-60^{\circ} \mathrm{N}$ minus EQ-25 $\mathrm{N}, 80^{\circ} \mathrm{E}-140^{\circ} \mathrm{E}$ & $3.22 \pm 1.14$ & $2.70 \pm 2.16$ \\
$\mathrm{U} 850$ in $20^{\circ} \mathrm{N}-30^{\circ} \mathrm{N}, 110^{\circ} \mathrm{E}-140^{\circ} \mathrm{E}$ minus $\mathrm{U} 850$ in $5^{\circ} \mathrm{N}-15^{\circ} \mathrm{N}, 90^{\circ} \mathrm{E}-130^{\circ} \mathrm{E}\left(\mathrm{m} \mathrm{s}^{-1}\right)$ & $0.05 \pm 0.28$ & $0.24 \pm 0.69$ \\
\hline
\end{tabular}




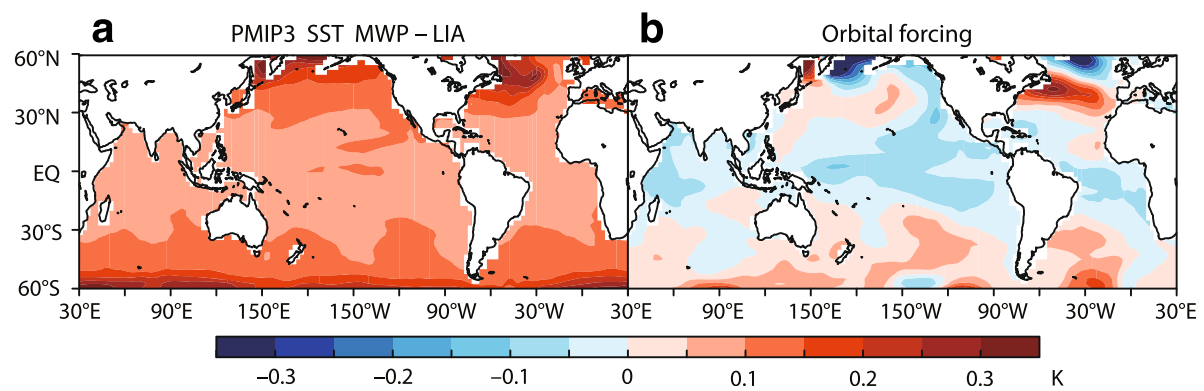

Fig. $5 \mathrm{ML}$ anomaly in annual-mean SST (K). a PMIP3 10-model ensemble mean. b MRI-CGCM2.3 orbital forcing runs

These seasonally asymmetric responses are difficult to understand as a forced response to seasonally uniform forcing that includes TSI and GHGs (e.g., Ueda et al. 2006; Endo and Kitoh 2014). Here, the seasonal NH insolation anomaly due to changes in orbital parameters (Table 2) has opposite signs in AMJ and ASO (Fig. 1), consistent with the Asian monsoon response. In this section, results of the orbital forcing runs conducted in MRI-CGCM2.3 are compared with the PMIP3 ensemble to examine the physical relationship between orbital parameters and the Asian monsoon.

Figure 6 shows the results of the five-member ensemble simulations with prescribed MWP and LIA orbital parameters. The ML rainfall anomaly is largely negative over Southeast Asia and Southern China $\left(15^{\circ} \mathrm{N}-35^{\circ} \mathrm{N}\right.$, $90^{\circ} \mathrm{E}-120^{\circ} \mathrm{E}$ ) in AMJ (Fig. 6a). The AMJ negative anomaly is indicative of a delay in the seasonal migration of the Asian summer monsoon, similar to the PMIP3 results (Fig. 2a). In ASO, positive anomalies are found over the Indian subcontinent, Southeast Asia, and southern China (Fig. 6b). However, negative anomalies are also found over the Bay of Bengal and the Yellow River Basin, distinct from the PMIP3 ensemble mean (detailed below). The seasonal sign reversal (from negative to positive) of the rainfall anomaly averaged over the Asian region (Fig. 6) is qualitatively consistent with the PMIP3 model ensemble (Table 3 ). Figures 7 and 8 show the seasonal responses of tropospheric thickness and rainfall. An negative tropospheric temperature anomaly in AMJ and a positive one in ASO are broadly found over the mid-latitude Eurasian continent, similar to the PMIP3 outcomes. Associated easterly anomalies over northeastern, eastern and southern China and southern India are found in AMJ, in contrast to an ASO westerly anomaly over Japan, northeastern and eastern China, and western India. The signs of the rainfall and tropospheric temperature anomalies over Asia reverse by season from negative to positive (Fig. 8a, b), largely similar to the PMIP3 results (Figs. 3, 4). This suggests that orbital forcing is an important factor in the differing monsoon responses of the MWP and LIA.

The simulated responses to orbital forcing are somewhat different from the PMIP3 multimodel mean. The Asian rainfall anomaly (negative during AMJ and positive during ASO; Figs. 6, 8a) is generally weaker and less spatially uniform than that estimated by the PMIP3 (Figs. 2, 4a), contributing to less statistical significance (Table 3). The simulated ML anomaly in the tropical SST is generally negative, while the PMIP3 multimodel mean shows a positive anomaly (Fig. 5). Tropospheric

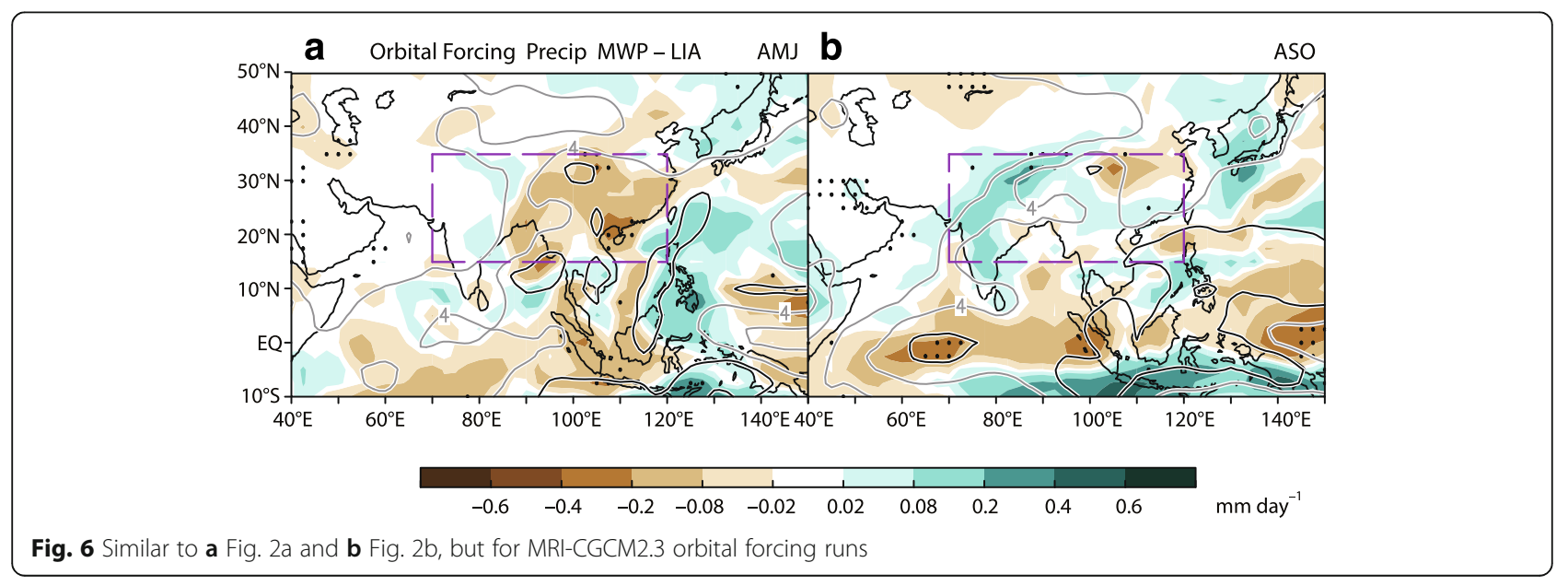




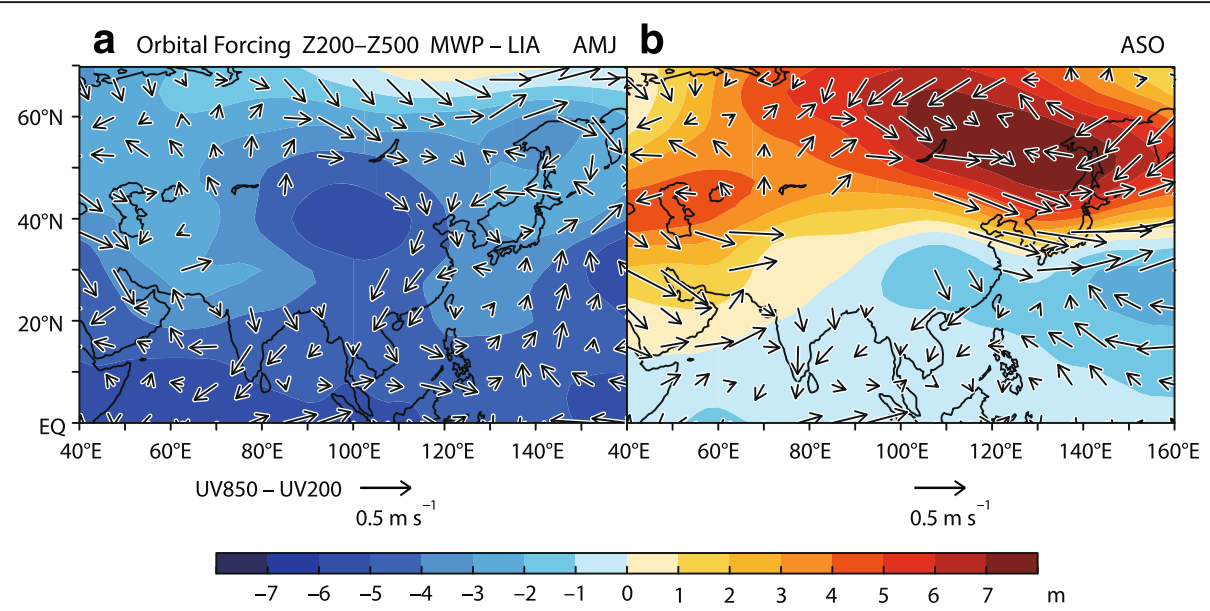

Fig. 7 Similar to a Fig. 6a and b Fig. 6b, but for tropospheric thickness (shading; m) between 200 and 500 hPa levels and vertical wind shear (vector; $\mathrm{ms}^{-1}$ ) between 850 and $200 \mathrm{hPa}$ levels

temperature has a larger negative anomaly in AMJ and a smaller positive ASO anomaly, and is less zonally uniform (Figs. 6, 7, and 8b) than in the PMIP3 (Figs. 3, 4b). In the next section, we discuss the limitations of the sensitivity experiments we conducted to quantify effects of orbital forcing on Asian monsoon variability over the last millennium.

\section{Possible importance of other external forcing factors}

The idealized orbital forcing run examined in the previous section reproduces seasonal asymmetry in the Asian monsoon rainfall and circulation anomalies similar to the PMIP3 model ensemble mean. However, these two (the PMIP3 and orbital forcing run) also show distinct regional responses. The PMIP3 model ensemble mean produces larger ML temperature and rainfall anomalies (warmer and wetter during the MWP than the LIA in both AMJ and ASO; Figs. 2, 3, 4, 5a) than the orbital forcing run (Figs. 5b, 6, 7, 8). Especially, the ML tropical tropospheric temperature anomaly is broadly negative
$\left(\mathrm{EQ}-20^{\circ} \mathrm{N}\right)$ in the orbital forcing run (Fig. 7), resulting in a low-latitude circulation anomaly (e.g. westerly over northern India in AMJ) that is inconsistent with the PMIP3 (Fig. 3). The Asian rainfall anomaly is less zonally uniform than the PMIP3 estimates (Figs. 2, 6). These differences may be ascribed to less ML difference in the global-mean temperature between the MWP and LIA in the orbital forcing run than in the PMIP3 case. Phipps et al. (2013) also showed that the ML warming anomaly in the last-millennium orbital forcing run is smaller than in all forcing runs. The PMIP3 multimodel mean produces a larger global SST warming anomaly during the MWP than in the LIA, particularly over the middle and high latitudes (Fig. 5a), in contrast to the tropical-wide negative SST anomaly that the orbital forcing run estimates (Fig. 5b). This SST difference may make a substantial contribution to the difference in the mid-to-upper tropospheric temperatures, where we see a cooler troposphere in the orbital forcing run than the PMIP3 as in Figs. 3 and 7 (Ueda et al. 2006; Kamae et al. 2015). In
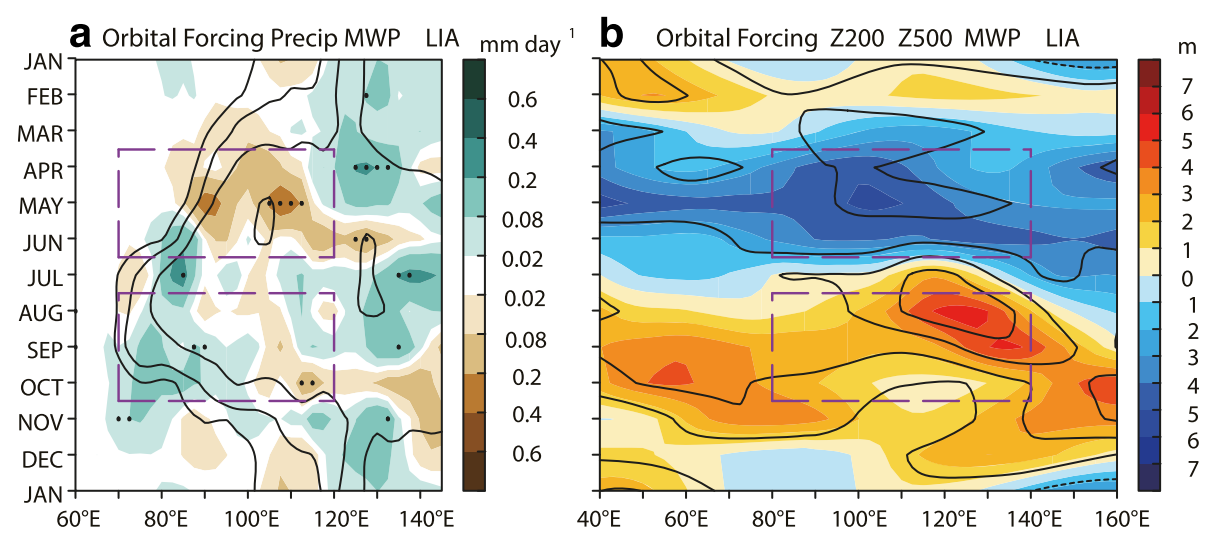

Fig. 8 Similar to $\mathbf{a}$ Fig. $4 a$ and $\mathbf{b}$ Fig. 4b, but for orbital forcing runs 
contrast to increased summer insolation (Fig. 1), winter insolation inversely decreases over the $\mathrm{NH}$ and $\mathrm{SH}$, resulting in limited global-mean annual-mean insolation anomalies. This limited global-mean forcing cannot simply explain the globally-warmer climate during the MWP than in the LIA (Fig. 5a). Under the PMIP3 framework, GHGs, volcanic aerosols, TSI, and land cover all varied over time in the climate model simulations in addition to the orbital forcing. For example, the $\mathrm{CO}_{2}$ concentration during the MWP is higher than in the LIA, especially after 1600 A.D. (Schmidt et al. 2011), contributing partly to global warming and the larger summertime tropospheric warming over the Eurasian continent than over the surrounding oceans as shown in Fig. 3b (Kamae et al. 2014). In addition, TSI and large volcanic eruptions are also important factors in the $\mathrm{ML}$ climate anomaly (e.g., Schurer et al. 2014; Otto-Bliesner et al. 2016). Phipps et al. (2013) showed that the lastmillennium temperature variation, in response to orbital forcing, is smaller than that in response to all forcing factors. Orbital forcing is substantially important for the seasonally asymmetric Asian monsoon response (Fig. 8) although it is a minor factor in the global ML climate anomaly (Fig. 5). The effect of volcanic eruptions on the SST anomaly is also discussed in the next subsection.

\section{Role of sea surface temperature pattern}

The PMIP3 multi-model mean reproduces general sea surface warming during the MWP than during the LIA (Fig. 5a). We should note that the spatial pattern of the ML SST anomaly and associated regional anomalies in the Asian and Western North Pacific monsoon (rainfall and atmospheric circulation) are highly dependent on the models used, as can be seen in Table 3 as per Shi et al. (2016b), who compared ML SST anomalies simulated in the individual PMIP3 models and found that (1) generally, mid-to-high latitude warming is larger than in the tropics; and (2) inter-model spread in the regional SST anomaly is substantially large over the equatorial Pacific and the mid-latitude North Pacific. A majority of the PMIP3 models simulate global ocean warming with limited east-west gradients in the equatorial Pacific (Mann et al. 2009; Shi et al., 2016b). In contrast, one PMIP3 model, MRI-CGCM3, reproduces a La Niñalike SST anomaly, largely consistent with proxy evidence (Mann et al. 2009; Shi et al., 2016b). This equatorial Pacific SST anomaly contributes to the simulated East Asian rainfall anomaly (Shi et al., 2016b). These results indicate that the reproducibility of the SST pattern over the tropical Pacific and the western North Pacific is essential in simulations of the Asian monsoon for the last millennium.

It is also noteworthy that large uncertainties still exist in the centennial variability of the equatorial Pacific SST associated with ENSO activity and tropical volcanic eruptions during the last millennium (e.g., Adams et al. 2003). Mann et al. (2009) revealed that positive tropical radiative forcing due to high solar irradiance and inactive volcanism are responsible for the more La Niña-like mean state during the MWP as compared to the LIA, inconsistent with a more El Niño-like condition suggested in Yan et al. (2011). In the near future, we plan to conduct a set of atmospheric simulations prescribing tropical SST patterns (i.e., La Niña-like and El Niño-like patterns) to evaluate the relative importance of the SST patterns to regional and seasonal Asian rainfall and the effect of orbital forcing-induced landsea warming contrast.

\section{Data-model and model-model comparisons}

A variety of proxy records for the last millennium Asian monsoon could improve our understanding of the long-term variation in the Asian monsoon's seasonal transition. However, it is not easy to procure such records because temporally high-resolution (i.e., sub-seasonal) information is needed to evaluate datamodel consistency in the seasonal monsoon transition. One of promising data source for this purpose is meteorological information in historical documents including diaries. Adamson and Nash (2014) reconstructed regional monsoon behavior over western India for the period 1781-1860 from diaries and other historical documents. They converted qualitative information in the historical documents into a quantitative monthly rainfall index. Wang and Zhang (1992) reviewed several studies trying to reconstruct the historical variation of monthly rainfall and onset/withdrawal dates of the Meiyu rainy season in the Lower Yangtze region in the 18 th century. Daily meteorological information recorded in historical documents is beneficial for reconstructing the variability of the Asian summer monsoon. However, such meteorological records were rarely continued for even several decades, let alone centuries, so they are not broadly effective in evaluating long-term monsoon variability. Further efforts to reconstruct past climate variability over Asia by combining a variety of proxy data including tree-ring records (e.g., Cook et al. 2013; Fan et al., 2009a; Fritts 2001; Takahashi et al. 2011), lake-freezing records (e.g., Arakawa 1954, Sharma et al. 2016), and phenological records (e.g. Aono and Omoto 1994; Mikami 2008) may improve our understanding of the long-term variability of the Asian monsoon.

In this study, the effect of orbital forcing is evaluated using only a single climate model. The derived results suffer from model-dependency problems including the effects of model biases. More systematic efforts are needed to better evaluate each particular forcing effect 
and the results' dependency on models. Previous studies have only evaluated the effects of respective forcing on continental-scale, NH-mean, or global-mean climate features (e.g., Phipps et al. 2013; Schurer et al. 2013, 2014; Otto-Bliesner et al. 2016). Monsoon responses to historical land use changes (e.g., Takata et al. 2009), aerosol forcing (e.g., Bollasina et al. 2011; Polson et al. 2014), and TSI (e.g., Shi et al. 2014) should be further evaluated in a multi-model framework. Further modeling work may contribute to better understanding of the forced monsoon response and its internal variability on interannual, decadal, centennial, and millennial timescales.

\section{Conclusions}

We examined long-term variation in the seasonal transition of the Asian monsoon during the last millennium using ten climate model simulations. The models reproduce an enhanced late summer MWP Asian monsoon but weakened early summer Asian rainfall compared to the LIA. The cooling-to-warming transition over the Eurasian continent before and after June with limited variation over the oceans results in the seasonally asymmetric deep-tropospheric circulation and rainfall responses over Asia. The robust seasonal asymmetry in the Asian monsoon response among the climate models is qualitatively reproduced by an AOGCM simulation forced by orbital parameters, suggesting that the seasonal-latitudinal distribution of the insolation anomaly is important to the centennial variability of the seasonal transition of the Asian monsoon.

Orbital forcing cannot explain the annual-mean climate anomaly between the MWP and LIA, implying that other forcing factors, including GHGs, have large contributions. Tropical SST response to orbital forcing in particular differs from the multiple model simulations. This inconsistency contributes to the tropospheric temperature and circulation anomaly over Asia. The east-west SST pattern in the Pacific shows remarkable inter-model variance, contributing substantially to the mid-latitude terrestrial climate anomaly between the MWP and LIA (Shi et al., 2016b). The La Niña-like ML SST anomaly in the Pacific suggested by proxy records was not successfully reproduced in the majority of climate model simulations. Uncertainty in centennial tropical SST variability and its contribution to the monsoon during the last millennium still remains a challenge. Further efforts in data-model synthesis including comparisons of simulation outputs with paleoenvironment reconstructions and paleoclimate data assimilation (e.g., von Storch et al. 2000; Fang and Li 2016) are needed to advance our understanding of the last millennium's monsoon variability.

\section{Abbreviations}

AMJ: April-May-June; AOGCM: Atmosphere-ocean coupled general circulation model; ASO: August-September-October; CMIP5: Coupled Model Intercomparison Project phase 5; GHGs: Greenhouse gases; JJA: June-JulyAugust; LGM: Last Glacial Maximum; LIA: Little Ice Age; ML: MWP minus LIA; MRI: Meteorological Research Institute; MRI-CGCM2.3: MRI Coupled General Circulation Model version 2.3; MWP: Medieval Warm Period; NH: Northern Hemisphere; PMIP3: Paleoclimate Modelling Intercomparison Project Phase 3; SH: Southern Hemisphere; SST: Sea surface temperature; TSI: Total solar irradiance

\section{Acknowledgements}

We thank two anonymous reviewers whose suggestions helped to greatly improve the manuscript. The MRI made the MRI-CGCM2.3 available under a cooperative agreement. We acknowledge the World Climate Research

Programme's Working Group on Coupled Modeling, which is responsible for the CMIP, and thank the climate modeling groups listed in Table 1 for producing and making their model output available. For CMIP5/PMIP3, the US Department of Energy's Program for Climate Model Diagnosis and Intercomparison provided coordinating support, and led the development of the software infrastructure in partnership with the Global Organization for Earth System Science Portals.

\section{Funding}

This work was supported by JSPS KAKENHI Grant Numbers 17 K14388 and $17 \mathrm{~K} 01223$.

\section{Availability of data and materials}

The PMIP3 experimental data are available from the CMIP5 Earth System Grid Federation data portal. The boundary forcing data for the PMIP3 experiments are available as supplemental data of Schmidt et al. (2011, 2012). The model outputs from the orbital-forcing sensitivity experiments are accessible via the authors.

\section{Authors' contributions}

YK drafted the manuscript. YK, MO, and $\mathrm{HU}$ proposed the topic and conceived and designed the study. TK and $\mathrm{MO}$ analyzed the multi-model data and helped in interpretation. YK conducted the sensitivity experiments and analyzed the simulated results. All authors read and approved the final manuscript.

\section{Authors' information}

MO's current affiliation is Weathernews Inc.

\section{Competing interests}

The authors declare that they have no competing interest.

\section{Publisher's Note}

Springer Nature remains neutral with regard to jurisdictional claims in published maps and institutional affiliations.

\section{Author details \\ ${ }^{1}$ Faculty of Life and Environmental Sciences, University of Tsukuba, 1-1-1 Tennoudai, Tsukuba, Ibaraki 305-8506, Japan. ${ }^{2}$ Scripps Institution of Oceanography, University of California San Diego, 9500 Gilman Drive, MC 206, La Jolla, CA 92093-0206, USA. ${ }^{3}$ College of Geoscience, School of Life and Environmental Sciences, University of Tsukuba, 1-1-1 Tennoudai, Tsukuba, Ibaraki 305-8506, Japan. ${ }^{4}$ Graduate School of Life and Environmental Sciences, University of Tsukuba, 1-1-1 Tennoudai, Tsukuba, Ibaraki 305-8506, Japan.}

Received: 2 March 2017 Accepted: 10 July 2017

Published online: 04 August 2017

\footnotetext{
References

Adams JB, Mann ME, Ammann CM (2003) Proxy evidence for an el Niño-like response to volcanic forcing. Nature 426:274-278

Adamson GCD, Nash DJ (2014) Documentary reconstruction of monsoon rainfall variability over western India, 1781-1860. Clim Dyn 42:749-769

Ammann CM, Joos F, Schimel DS, Otto-Bliesner BL, Tomas RA (2007) Solar influence on climate during the past millennium: results from transient simulations with the NCAR climate system model. Proc Natl Acad Sci U S A 104:3713-3718
} 
Aono Y, Omoto Y (1994) Estimation of temperature at Kyoto since the 11th century using flowering data of cherry trees in old documents. J Agr Meteorol Jpn 49:263-272

Arakawa $\mathrm{H}$ (1954) Fujiwhara on five centuries of freezing dates of Lake Suwa in the Central Japan. Arch Meteorol Geophys Bioklimatol Ser B 6:152-166

Battisti DS, Ding Q, Roe GH (2014) Coherent pan-Asian climatic and isotopic response to orbital forcing of tropical insolation. J Geophys Res Atmos 119: 11997-12020

Berger A, Loutre MF (1991) Insolation values for the climate of the last 10 million of years. Quat Sci Rev 10:297-317

Berkelhammer M, Sinha A, Mudelsee M, Cheng H, Yoshimura K, Biswas J (2014) On the low-frequency component of the ENSO-Indian monsoon relationship: a paired proxy perspective. Clim Past 10:733-744

Bollasina MA, Ming Y, Ramaswamy V (2011) Anthropogenic aerosols and the weakening of the south Asian summer monsoon. Science 334:502-505

Bosmans JHC, Hilgen FJ, Tuenter E, Lourens LJ (2015) Obliquity forcing of lowlatitude climate. Clim Past 11:1335-1346

Braconnot P, Otto-Bleisner B, Harrison S, Joussaume S, Peterschmitt J-Y, AbeOuchi A, Crucifix M, Driesschaert E, Fichefet T, Hewitt CD, Kagayama M, Kitoh A, La né A, Loutre M-F, Marti O, Merkel U, Ramstein G, Valdes P, Weber SL, Yu Y, Zhao Y (2007) Results of PMIP2 coupled simulations of the midHolocene and last glacial maximum, part 1: experiments and large-scale features. Clim Past 3:261-277

Bradley RS, Briffa KR, Cole J, Osborn TJ (2003) The climate of the last millennium. In: Alverson KD, Bradley RS, Pedersen TS (eds) Paleoclimate, global change and the future. Springer, Heidelberg, pp 105-141

Chen J, Chen F, Feng S, Huang W, Liu J, Zhou A (2015) Hydroclimatic changes in China and surroundings during the medieval climate anomaly and little ice age: spatial patterns and possible mechanisms. Quat Sci Rev 107:98-111

Clift PD, Plumb RA (2008) The Asian monsoon: causes, history \& effects. Cambridge University Press, Cambridge

COHMAP members (1988) Climatic changes of the last 18,000 years: observations and model simulations. Science 241:1043-1052

Cook ER, Krusic PJ, Anchukaitis KJ, Buckley BM, Nakatsuka T, Sano M (2013) Tree-ring reconstructed summer temperature anomalies for temperate East Asia since 800 CE. Clim Dyn 41:2957-2972

Crowley TJ (2000) Causes of climate change over the past 1000 years. Science 289:270-277

Crowley TJ, Zielinski G, Vinther B, Udisti R, Kreutz K, Cole-Dai J, Castellano E (2008) Volcanism and the little ice age. PAGES News 16:22-23

Dai A, Li H, Sun Y, Hong L-C, Lin H, Chou C, Zhou T (2013) The relative roles of upper and lower tropospheric thermal contrasts and tropical influences in driving Asian summer monsoons. J Geophys Res Atmos 118:7024-7045

Delaygue G, Bard E (2009) Solar forcing based on be-10 in Antarctica ice over the past millennium and beyond. EGU Gen Assembly Conf Abstr 11:6943

Endo H, Kitoh A (2014) Thermodynamic and dynamic effects on regional monsoon rainfall changes in a warmer climate. Geophys Res Lett 41:1704-1710

Fallah B, Cubasch U (2015) A comparison of model simulations of Asian megadroughts during the past millennium with proxy reconstructions. Clim Past 11:253-263

Fan Z-X, Bräuning A, Yang B, Cao K-F (2009a) Tree ring density-based summer temperature reconstruction for the central Hengduan Mountains in southern China. Glob Planet Change 65:1-11

Fan F, Mann ME, Amman CM (2009b) Understanding changes in the Asian summer monsoon over the past millennium: insights from a long-term coupled model simulation. J Clim 22:1736-1748

Fang M, Li X (2016) Paleoclimate data assimilation: its motivation, progress and prospects. Sci Chi Earth Sci 59:1817-1826

Fritts HC (2001) Tree rings and climate, 2nd edn. Blackburn Press, Caldwell

Fu C, Freney JR, Stewart JWB (eds) (2008) Changes in the human-monsoon system of East Asia in the context of global change. World Scientific Publishing, Singapore

Gao C, Robock A, Ammann C (2008) Volcanic forcing of climate over the past 1500 years: an improved ice core-based index for climate models. J Geophys Res Atmos 113:D23111. doi:10.1029/2008JD010239

Gray LJ, Beer J, Geller M, Haigh JD, Lockwood M, Matthes K, Cubasch U, Fleitmann D, Harrison G, Hood L, Luterbacher J, Meehl GA, Shindell D, van Geel B, White W (2010) Solar influences on climate. Rev Geophys 48:RG4001

He F, Vavrus SJ, Kutzbach JE, Ruddiman WF, Kaplan JO, Krumhardt KM (2014) Simulating global and local surface temperature changes due to Holocene anthropogenic land cover change. Geophys Res Lett 41:623-631
Inoue T, Ueda H (2009) Evaluation for the seasonal evolution of the summer monsoon over the Asian and western North Pacific sector in the WCRP CMIP3 multi-model experiments. J Meteorol Soc Jpn 87:539-560

Jones PD, Mann ME (2004) Climate over past millennia. Rev Geophys 42:RG2002. doi:10.1029/2003RG000143

Jones PD, Briffa KR, Osborn TJ, Lough JM, van Ommen TD, Vinther BM, Luterbacher J, Wahl ER, Zwiers FW, Mann ME, Schmidt GA, Ammann CM, Buckley BM, Cobb KM, Esper J, Goosse H, Graham N, Jansen E, Kiefer T, Kull C, Küttel M, Mosley-Thompson E, Overpeck JT, Riedwyl N, Schulz M, Tudhope AW, Villalba R, Wanner H, Wolff E, Xoplaki E (2009) High-resolution palaeoclimatology of the last millennium: a review of current status and future prospects. The Holocene 19:3-49

Kamae Y, Ueda H (2012) Mid-Pliocene global climate simulation with MRICGCM2.3: set-up and initial results of PlioMIP experiments 1 and 2. Geosci Model Dev 5:793-808

Kamae Y, Watanabe M, Kimoto M, Shiogama H (2014) Summertime land-sea thermal contrast and atmospheric circulation over East Asia in a warming climate-part I: past changes and future projections. Clim Dyn 43:2553-2568

Kamae Y, Shiogama H, Watanabe M, Ishii M, Ueda H, Kimoto M (2015) Recent slowdown of tropical upper tropospheric warming associated with Pacific climate variability. Geophys Res Lett 42:2995-3003

Kamae Y, Yoshida K, Ueda H (2016) Sensitivity of Pliocene climate simulations in MRI-CGCM2.3 to respective boundary conditions. Clim Past 12:1619-1634

Kamae Y, Li X, Xie S-P, Ueda H (2017) Atlantic effects on recent decadal trends in global monsoon. Clim Dyn. doi:10.1007/s00382-017-3522-3

Kathayat G, Cheng H, Sinha A, Spötl C, Edwards RL, Zhang H, Li X, Yi L, Ning Y, Cai Y, Lui WL, Breitenbach SFM (2016) Indian monsoon variability on millennial-orbital timescales. Sci Rep 6:24374

Kaufman DS, Schneider DP, McKay NP, Ammann CM, Bradley RS, Briffa KR, Miller GH, Otto-Bliesner BL, Overpeck JT, Vinther BM, Abbott M, Axford Y, Bird B, Birks HJB, Bjune AE, Briner J, Cook T, Chipman M, Francus P, Gajewski K, Geirsdóttir Á, Hu FS, Kutchko B, Lamoureux S, Loso M, Mac Donald G, Peros M, Porinchu D, Schiff C, Seppä H, Thomas E (2009) Recent warming reverses long-term Arctic cooling. Science 325:1236-1239

Kawamura R (1998) A possible mechanism of the Asian summer monsoon-ENSO coupling. J Meteorol Soc Jpn 76:1009-1027

Kitoh A, Motoi T, Murakami S (2007) El Niño-southern oscillation simulation at 6000 years before present with the MRI-CGCM2.3: effect of flux adjustment. J Clim 20:2484-2499

Kong W, Swenson L, Chiang J (2017) Seasonal transitions and the westerly jet in the Holocene east Asian summer monsoon. J Clim. doi:10.1175/JCLI-D-16-0087.1

Kutzbach JE, Liu XD, Liu ZY, Chen GS (2008) Simulating the evolution response of global monsoons to orbital forcing over the past 280,000 years. Clim Dyn 30: 567-579

Lean $\lrcorner$ (2010) Cycles and trends in solar irradiance and climate. WIREs Clim Change 1:111-122

Li CF, Yanai M (1996) The onset and interannual variability of the Asian summer monsoon in relation to land-sea thermal contrast. J Clim 9:358-375

Liu J, Wang B, Ding Q, Kuang X, Soon W, Zorita E (2009) Centennial variations of the global monsoon precipitation in the last millennium: results from ECHOG model. J Clim 22:2356-2371

Liu J, Wang B, Wang H, Kuang Z, Ti R (2011) Forced response of the east Asian summer rainfall over the past millennium: results from a coupled model simulation. Clim Dyn 36:323-336

Liu F, Chai J, Wang B, Liu J, Zhang X, Wang Z (2016) Global monsoon precipitation responses to large volcanic eruptions. Sci Rep 6:24331

Man W, Zhou T, Jungclaus JH (2012) Simulation of the east Asian summer monsoon during the last millennium with the MPI earth system model. J Clim 25:7852-7866

Mann ME, Zhang Z, Rutherford S, Bradley RS, Hughes MK, Shindell D, Ammann C, Faluvegi G, Ni F (2009) Global signatures and dynamical origins of the little ice age and medieval climate anomaly. Science 326:1256-1260

Masson-Delmotte V, Schulz M, Abe-Ouchi A, Beer J, Ganopolski A, González Rouco JF, Jansen E, Lambeck K, Luterbacher J, Naish T, Osborn T, OttoBliesner B, Quinn T, Ramesh R, Rojas M, Shao X, Timmermann A (2014) Information from Paleoclimate archives. In: Stocker TF et al (eds) Climate change 2013: the physical science basis. Contribution of working group I to the fifth assessment report of the intergovernmental panel on climate change. Cambridge University Press, Cambridge, pp 383-464

Merlis TM, Schneider T, Bordoni S, Eisenman I (2013) The tropical precipitation response to orbital precession. J Clim 26:2010-2021 
Mikami T (2008) Climatic variation in Japan reconstructed from historical documents. Weather 63:190-193

Miller GH, Geirsdóttir Á, Zhong Y, Larsen DJ, Otto-Bliesner BL, Holland MM, Bailey DA, Refsnider KA, Lehman SJ, Southon JR, Anderson C, Björnsson H, Thordarson T (2012) Abrupt onset of the little ice age triggered by volcanism and sustained by sea-ice/ocean feedbacks. Geophys Res Lett 39:L02708

Mohtadi M, Prange M, Steinke S (2016) Palaeoclimatic insights into forcing and response of monsoon rainfall. Nature 533:191-199

Oppo DW, Rosenthal Y, Linsley BK (2009) 2,000-year-long temperature and hydrology reconstructions from the indo-Pacific warm pool. Nature 460: 1113-1116

Otto-Bliesner BL, Joussaume S, Braconnot P, Harrison SP, Abe-Ouchi A (2009) Modeling and data syntheses of past climates. EOS Trans AGU. doi:10.1029/ 2009EO110013

Otto-Bliesner B, Brady E, Fasullo J, Jahn A, Landrum L, Stevenson S, Rosenbloom N, Mai A, Strand G (2016) Climate variability and change since 850 C.E.: an ensemble approach with the community earth system model (CESM). Bull Am Meteorol Soc 97:735-754

PAGES 2k Consortium (2013) Continental-scale temperature variability during the last two millennia. Nat Geosci 6:339-346

Phipps SJ, McGregor HV, Gergis J, Gallant AJE, Neukom R, Stevenson S, Ackerley D, Brown JR, Fischer MJ, van Ommen TD (2013) Paleoclimate data-model comparison and the role of climate forcings over the past 1500 years. J Clim 26:6915-6936

Polanski S, Fallah B, Befort DJ, Prasad S, Cubasch U (2014) Regional moisture change over India during the past millennium: a comparison of multi-proxy reconstructions and climate model simulations. Glob Planet Change 122:176-185

Polson D, Bollasina M, Hegerl GC, Wilcox LJ (2014) Decreased monsoon precipitation in the northern hemisphere due to anthropogenic aerosols. Geophys Res Lett 41:6023-6029

Qian W, Hu Q, Zhu Y, Lee D-K (2003) Centennial-scale dry-wet variations in East Asia. Clim Dyn 21:77-89

Ren G, Zhang L (1996) Climate of the medieval warm period in Maili region as inferred from fossil pollen record (in Chinese). Clim Env Res 1:81-86

Rojas M, Arias PA, Flores-Aqueveque V, Seth A, Vuille M (2016) The south American monsoon variability over the last millennium in climate models. Clim Past 12:1681-1691

Sachs JP, Sachse D, Smittenberg RH, Zhang Z, Battisti DS, Golubic (2009) Southward movement of the Pacific intertropical convergence zone AD 1400-1850. Nat Geosci 2:519-525

Schmidt GA, Jungclaus JH, Ammann CM, Bard E, Braconnot P, Crowley TJ Delaygue G, Joos F, Krivova NA, Muscheler R, Otto-Bliesner BL, Pongratz J, Shindell DT, Solanki SK, Steinhilber F, Vieira LEA (2011) Climate forcing reconstructions for use in PMIP simulations of the last millennium (v1.0). Geosci Model Dev 4:33-45

Schmidt GA, Jungclaus JH, Ammann CM, Bard E, Braconnot P, Crowley TJ, Delaygue G, Joos F, Krivova NA, Muscheler R, Otto-Bliesner BL, Pongratz J, Shindell DT, Solanki SK, Steinhilber F, Vieira LEA (2012) Climate forcing reconstructions for use in PMIP simulations of the last millennium (v1.1). Geosci Model Dev 5:185-191

Schneider T, Bischo T, Haug GH (2014) Migrations and dynamics of the intertropical convergence zone. Nature 513:45-53

Schurer AP, Hegerl GC, Mann ME, Tett SFB, Phipps SJ (2013) Separating forced from chaotic climate variability over the past millennium. J Clim 26:6954-6973

Schurer AP, Tett SFB, Hegerl GC (2014) Small influences of solar variability on climate over the past millennium. Nat Geosci 7:104-108

Sharma S, Magnuson JJ, Batt RD, Winslow JK, Aono Y (2016) Direct observations of ice seasonality reveal changes in climate over the past 320-570 years. Sci Rep 6:25061

Shi Z (2016) Response of Asian summer monsoon duration to orbital forcing under glacial and interglacial conditions: implication for precipitation variability in geological records. Quat Sci Rev 139:30-42

Shi F, Li JP, Wilson RJS (2014) A tree-ring reconstruction of the south Asian summer monsoon index over the past millennium. Sci Rep 4:6739

Shi Z, Xu T, Wang H (2016a) Sensitivity of Asian climate change to radiative forcing during the last millennium in a multi-model analysis. Glob Planet Change 139:195-210

Shi J, Yan Q, Jiang D, Min J, Jiang Y (2016b) Precipitation variation over eastern China and arid central Asia during the past millennium and its possible mechanism: perspectives from PMIP3 experiments. J Geophys Res Atmos 121:11989-12004
Sinha A, Berkelhammer M, Stott L, Mudelsee M, Cheng H, Biswas J (2011) The leading mode of Indian summer monsoon precipitation variability during the last millennium. Geophys Res Lett 38:L15703. doi:10.1029/2011gl047713

Sinha A, Kathayat G, Cheng H, Breitenbach SFM, Berkelhammer M, Mudelsee M, Biswas J, Edwards RL (2015) Trends and oscillations in the Indian summer monsoon rainfall over the last two millennia. Nat Commun 6:6309

Smerdon JE, Pollack HN (2016) Reconstructing Earth's surface temperature over the past 2000 years: the science behind the headlines. WIREs Clim Change 7: 746-771

Steinhilber F, Beer J, Fröhlich C (2009) Total solar irradiance during the Holocene. Geophys Res Lett 36:L19704. doi:10.1029/2009GL040142

von Storch H, Cubasch U, Gonzalez-Rouco JF, Jones JM, Voss R, Widmann M, Zorita E (2000) Combining paleoclimatic eviedence and GCMs by means of data assimilation though upscaling and nudging (DATUN). In: Proc 11th symposium on global climate change studies. AMS Long Beach, CA

Sueyoshi T, Ohgaito R, Yamamoto A, Chikamoto MO, Hajima T, Okajima H, Yoshimori M, Abe M, O'ishi R, Saito F, Watanabe S, Kawamiya M, Abe-Ouchi A (2013) Set-up of the PMIP3 paleoclimate experiments conducted using an earth system model, MIROC-ESM. Geosci Model Dev 6:819-836

Takahashi K, Okuhara I, Tokumitsu Y, Yasue K (2011) Responses to climate by treering widths and maximum latewood densities of two Abies species at upper and lower altitudinal distribution limits in central Japan. Trees 25:745-753

Takata K, Saito K, Yasunari T (2009) Changes in the Asian monsoon climate during 1700-1850 induced by preindustrial cultivation. Proc Natl Acad Sci U S A 106:9586-9589

Tan M (2007) Climatic differences and similarities between Indian and east Asian monsoon regions of China over the last millennium: a perspective based mainly on stalagmite records. Int J Speleol 36:75-81

Tao S, Chen $L$ (1987) A review of recent research on the east Asian summer monsoon in China. In: Chang C-P, Krishnamurti TN (eds) Monsoon meteorology. Oxford University Press, Oxford, pp 60-92

Taylor KE, Stouffer RJ, Meehl GA (2012) An overview of CMIP5 and the experiment design. Bull Am Meteorol Soc 90:485-498

Ueda H, Iwai A, Kuwako K, Hori ME (2006) Impact of anthropogenic forcing on the Asian summer monsoon as simulated by 8 GCMs. Geophys Res Lett 33 L06703. doi:10.1029/2005GL025336

Ueda H, Ohba M, Xie S-P (2009) Important factors for the development of the Asian-Northwest Pacific summer monsoon. J Clim 22:649-669

Ueda H, Kuroki H, Ohba M, Kamae Y (2011) Seasonally asymmetric transition of the Asian monsoon in response to ice age boundary conditions. Clim Dyn 37:2167-2179

Vieira LEA, Solanki SK, Krivova NA, Usoskin I (2011) Evolution of the solar irradiance during the Holocene. Astr Astrophys 531:A6. doi:10.1051/0004$6361 / 201015843$

Wang B, Lin H (2002) Rainy season of the Asian-Pacific summer monsoon. J Clim 15:386-398

Wang PK, Zhang D (1992) Recent studies of the reconstruction of east Asian monsoon climate in the past using historical literature of China. J Meteorol Soc Jpn 70:423-446

Wang S, Gong D, Zhu J (2001) Twentieth-century climatic warming in China in the context of the Holocene. The Holocene 11:313-321

Wang B, Wu Z, Li J, Liu J, Chang C-P, Ding Y, Wu G (2008) How to measure the strength of the east Asian summer monsoon. J Clim 21:4449-4463

Webster PJ, Yang S (1992) Monsoon and ENSO: selectively interactive systems. Quart J Roy Meteorol Soc 118:877-926

Webster PJ, Magaña VO, Palmer TN, Shukla J, Tomas RA, Yanai M, Yasunari T (1998) Monsoons: processes, predictability, and the prospects for prediction. J Geophys Res 103(C7):14451-14510

Wu G, He B, Liu Y, Bao Q, Ren R (2015) Location and variation of the summertime upper-troposphere temperature maximum over South Asia. Clim Dyn 45:2757-2774

Wu C-H, Lee S-Y, Chiang JCH, Hsu H-H (2016) The influence of obliquity in the early Holocene Asian summer monsoon. Geophys Res Lett 43:4524-4530

Yan H, Sun L, Wang Y, Huang W, Qiu S, Yang C (2011) A record of the southern oscillation index for the past 2,000 years from precipitation proxies. Nat Geosci 4:611-614

Yan H, Wei W, Soon W, An Z, Zhou W, Liu Z, Wang Y, Carter RM (2015) Dynamics of the intertropical convergence zone over the western Pacific during the little ice age. Nat Geosci 8:315-320

Yanai M, Wu G-X (2006) Effects of the Tibetan plateau. In: Wang B (ed) The Asian monsoon. Springer, Heidelberg, pp 513-549 
Yang K, Jiang D (2015) Interannual climate variability of the past millennium from simulations. Atmos Ocean Sci Lett 8:160-165

Yang K, Jiang D (2017) Interannual climate variability change during the medieval climate anomaly and little ice age in PMIP3 last millennium simulations. Adv Atmos Sci 34:497-508

Yukimoto S, Noda A, Kitoh A, Hosaka M, Yoshimura H, Uchiyama T, Shibata K, Arakawa O, Kusunoki S (2006a) Present-day and climate sensitivity in the meteorological research institute coupled GCM version 2.3 (MRI-CGCM2.3). J Meteorol Soc Jpn 84:333-363

Yukimoto S, Noda A, Uchiyama T, Kusunoki S, Kitoh A (2006b) Climate changes of the twentieth through twenty-first centuries simulated by the MRI-CGCM2.3. Pap Meteorol Geophys 56:9-24

Zhang R, Cheng H, Lawrence Edwards R, Chen F, Wang Y, Yang X, Liu J, Tan M, Wang X, Liu J, An C, Dai Z, Zhou J, Zhang D, Jia J, Jin L, Johnson KR (2008) A test of climate, sun, and culture relationships from an 1810-year Chinese cave record. Science 322:940-942

Zhang P, Liu Y, He B (2016) Impact of east Asian summer monsoon heating on the interannual variation of the south Asian high. J Clim 29:159-173

\section{Submit your manuscript to a SpringerOpen ${ }^{\odot}$ journal and benefit from:}

- Convenient online submission

Rigorous peer review

- Open access: articles freely available online

- High visibility within the field

- Retaining the copyright to your article

Submit your next manuscript at $\gg$ springeropen.com 